\title{
The ties that bind: functional clusters in limb-girdle muscular dystrophy
}

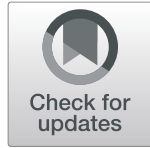

Elisabeth R. Barton 1,2 (D), Christina A. Pacak ${ }^{2,3}$, Whitney L. Stoppel ${ }^{2,4}$ and Peter B. Kang $2,5,6,7,8^{*}$

\begin{abstract}
The limb-girdle muscular dystrophies (LGMDs) are a genetically pleiomorphic class of inherited muscle diseases that are known to share phenotypic features. Selected LGMD genetic subtypes have been studied extensively in affected humans and various animal models. In some cases, these investigations have led to human clinical trials of potential disease-modifying therapies, including gene replacement strategies for individual subtypes using adeno-associated virus (AAV) vectors. The cellular localizations of most proteins associated with LGMD have been determined. However, the functions of these proteins are less uniformly characterized, thus limiting our knowledge of potential common disease mechanisms across subtype boundaries. Correspondingly, broad therapeutic strategies that could each target multiple LGMD subtypes remain less developed. We believe that three major "functional clusters" of subcellular activities relevant to LGMD merit further investigation. The best known of these is the glycosylation modifications associated with the dystroglycan complex. The other two, mechanical signaling and mitochondrial dysfunction, have been studied less systematically but are just as promising with respect to the identification of significant mechanistic subgroups of LGMD. A deeper understanding of these disease pathways could yield a new generation of precision therapies that would each be expected to treat a broader range of LGMD patients than a single subtype, thus expanding the scope of the molecular medicines that may be developed for this complex array of muscular dystrophies.
\end{abstract}

\section{Key points}

- There is a diverse array of genetic subtypes of limbgirdle muscular dystrophy (LGMD).

- The cellular localizations of various proteins associated with LGMD have been characterized, but currently there is little knowledge of unifying disease mechanisms across multiple subtypes.

- We propose that functional clusters of LGMD proteins can illuminate disease mechanisms that are shared across disease subtypes and identify potential therapeutic targets.

\footnotetext{
* Correspondence: pbkang@ufl.edu

${ }^{2}$ Myology Institute, University of Florida, Gainesville, FL, USA

${ }^{5}$ Division of Pediatric Neurology, Department of Pediatrics, University of Florida College of Medicine, PO Box 100296, Gainesville, FL 32610, USA

Full list of author information is available at the end of the article
}

- One functional cluster that has been defined better than others is composed of the dystroglycanopathies.

- Two other functional clusters that bear further study are mechanical signaling defects and mitochondrial dysfunction.

\section{Introduction}

In the field of inherited neuromuscular diseases, the primary goal is to identify the underlying genetic cause of the disease, ultimately to understand mechanisms driving pathology, and by doing so, develop effective therapeutic strategies. Nineteen eighty-six was a pivotal year, when the $D M D$ gene associated with Duchenne muscular dystrophy (DMD) was discovered [1], followed the next year by the identification of the encoded protein dystrophin [2]. Similarly in the mid-1990s, the 
SMN1 gene associated with the most common form of spinal muscular atrophy (SMA) was discovered [3]. These and many other similar discoveries led to international efforts to understand the underlying disease processes and to develop therapeutic strategies targeting the fundamental genetic defects. These endeavors have recently begun to yield remarkable new precision medicines. DMD and SMA are among the most common inherited neuromuscular disorders, yet both are rare diseases; birth prevalence ranges from 15.9 to 19.5 per 100 , 000 for DMD [4] and 7.8 to 10 per 100,000 for SMA [5, $6]$. It is not clear how such precise gene-specific and mutation-specific therapeutic development pipelines can be extended to diseases that are even rarer in an economically sustainable manner. Furthermore, it has become apparent that direct replacement of deficient genes face technical barriers in humans such as immune responses [7] and that, even if successful, such therapies may not necessarily be curative. Specifically, the progression of any neuromuscular disease leads to secondary consequences, including fatty-fibrotic replacement of muscle, and motor unit compression or loss, which may have already occurred by the time the gene therapy is administered [8].

LGMD, a category of muscular dystrophy distinct from DMD, presents two major dilemmas with respect to precision medicine approaches. The first is that even collectively, LGMDs as a whole are rarer than DMD or SMA, with an estimated prevalence of 1.63 to 2.27 per $100,000[9,10]$; in a large population-based surveillance study, LGMDs composed $9.1 \%$ of all muscular dystrophies identified $[11,12]$. The second is that unlike these other two diseases, LGMD is composed of an astonishing diversity of genetic etiologies, numbering at least 30 and counting. The numbers have grown so large that they have outgrown the traditional classification system, resulting in a new recently adopted system [13] (Tables 1 and 2). The recessive forms are more common than the dominant ones, with one recent study finding an $84 \% / 16 \%$ distribution in a large cohort from Italy [64]. In large, genetically heterogeneous populations, certain subtypes such as LGMD R1 (CAPN3), LGMD R2 (DYSF), LGMD R3 (SGCA), LGMD R4 (SGCB), LGMD R5 (SGCG), LGMD R6 (SGCD), LGMD R9 (FKRP), and LGMD R12 (ANO5) tend to be relatively common [64, 65], with founder effects in specific regions making it difficult to calculate worldwide prevalence for any particular subtype [12, 66-79]. In contrast, the other subtypes are exceedingly rare except in some genetically isolated populations; many have only been described in certain regions of the world, and there remain a large number of genetically unsolved LGMD cases, both in clinical cohorts [80, 81] and research cohorts [53, 68, 82, 83]. The search for genetic diagnoses in these cases paves the way for potential precision medicine strategies, but the diagnostic odyssey can be quite prolonged for certain individuals, thus delaying definitive genetic counseling and potential eligibility for clinical trials as well as novel therapies that are likely to be approved in coming years.

\section{Therapeutic strategies for individual LGMDs}

A widening stream of increasingly sophisticated molecular therapies is under development for individual LGMD subtypes. Though none has been approved by the FDA to date, it is becoming increasingly likely that such approvals will occur in the near future. Single gene replacement strategies have been investigated in animal models for some time, primarily using adeno-associated virus (AAV) vectors that contain DNA sequences for individual LGMD genes, such as CAPN3 [84, 85], DYSF [86-89], FKRP [90-93], SGCA [94-100], SGCB [95, 101, $102]$, and $S G C D$ [103-105], and SGCG [106, 107]. Such efforts have accelerated and moved into human clinical trials for genes such as SGCG [108], inspired in part by an FDA-approved gene therapy for spinal muscular atrophy [109] and ongoing human studies of microdystrophin gene therapy for DMD [110]. Host immune responses have been a major concern in the implementation of gene therapy for human patients [111]. For various subtypes of LGMD, the residual protein expression may not only explain the milder phenotypes seen in some affected individuals but also has the potential to spare patients from host immune responses to the transgene in the setting of gene therapy approaches [112].

Compensation for and correction of specific mutations has also been studied. Antisense oligonucleotides have been used to rescue specific DYSF mutations [113], as well as the most common pathogenic SGCG mutation $[114,115]$, both in mouse models. CRISPR-Cas9 genome editing was used to correct mutations in induced pluripotent stem cells (iPSCs) derived from human patients with CAPN3 mutations, and those corrected cells were able to treat Capn3 deficiency in a mouse model [116].

There have been some attempts to deliver one LGMD-associated gene using AAV in hopes of rescuing a different LGMD subtype in cases where the two protein products share functional overlap. However, these studies have been largely disappointing to date, including an investigation of ANO5 delivery into DYSF deficient mice, with a rationale that both protein products participate in sarcolemmal membrane resealing [117]. The membrane-resealing pathway has also been targeted via overexpression of MG53, with some promising results in mouse models of SGCD [118] and DYSF [119] deficiencies. The development of molecular therapies that target more than one LGMD subtype should be feasible. However, it is clear that we do not know enough about 
Table 1 Recessive forms of LGMD, listed by the new 2018 classification system [13], with old subtype nomenclature in parentheses

\begin{tabular}{|c|c|c|c|c|}
\hline Subtype & Gene & Protein & $\begin{array}{l}\text { Cellular } \\
\text { localization }\end{array}$ & Protein function \\
\hline LGMD R1 (LGMD2A) & CAPN3 [14] & Calpain 3 & Myofibril [15] & Cysteine protease \\
\hline LGMD R2 (LGMD2B) & DYSF $[16,17]$ & Dysferlin & Sarcolemma & $\begin{array}{l}\text { Membrane } \\
\text { resealing }[18,19]\end{array}$ \\
\hline LGMD R3 (LGMD2D) & SGCA [20] & a-Sarcoglycan & Sarcolemma & Mechanosensor \\
\hline LGMD R4 (LGMD2E) & $\operatorname{SGCB}[21,22]$ & $\beta$-Sarcoglycan & Sarcolemma & Mechanosensor \\
\hline LGMD R5 (LGMD2C) & SGCG [23] & Y-Sarcoglycan & Sarcolemma & Mechanosensor \\
\hline LGMD R6 (LGMD2F) & SGCD [24] & $\delta$-Sarcoglycan & Sarcolemma & Mechanosensor \\
\hline LGMD R7 (LGMD2G) & TCAP [25] & Telethonin & Sarcomere & $\begin{array}{l}\text { Sarcomere assembly } \\
\text { and maintenance [26] }\end{array}$ \\
\hline LGMD R8 (LGMD2H) & TRIM32 [27] & TRIM32 & Myofibril [28] & E3-ubiquitin-ligase \\
\hline LGMD R9 (LGMD2I) & FKRP [29] & Fukutin-related protein & Golgi apparatus & Glycosylation \\
\hline LGMD R10 (LGMD2J) & $\pi \mathrm{TN}[30]$ & Titin & Sarcomere [31] & Various \\
\hline LGMD R11 (LGMD2K) & POMT1 [32] & Protein O-mannosyltransferase 1 & $\begin{array}{l}\text { Endoplasmic } \\
\text { reticulum }\end{array}$ & Glycosylation \\
\hline LGMD R12 (LGMD2L) & ANO5 [33] & Anoctamin5 & Sarcolemma & Membrane resealing \\
\hline LGMD R13 (LGMD2M) & FKTN $[34,35]$ & Fukutin & Golgi apparatus & Glycosylation \\
\hline LGMD R14 (LGMD2N) & POMT2 [36] & Protein O-mannosyltransferase 2 & $\begin{array}{l}\text { Endoplasmic } \\
\text { reticulum }\end{array}$ & Glycosylation \\
\hline LGMD R15 (LGMD2O) & $\begin{array}{l}\text { POMGnT1 [37, } \\
\text { 38] }\end{array}$ & $\begin{array}{l}\text { Protein O-linked mannose } \mathrm{N} \text { - } \\
\text { acetylglucosaminyltransferase } 1\end{array}$ & Golgi apparatus & Glycosylation \\
\hline LGMD R16 (LGMD2P) & DAG1 [39] & Dystroglycan 1 & Extracellular matrix & $\begin{array}{l}\text { Stabilize sarcomeric } \\
\text { cytoskeleton [40] }\end{array}$ \\
\hline LGMD R17 (LGMD2Q) & PLEC [41] & Plectin & Cytosol & $\begin{array}{l}\text { Stabilize intermediate } \\
\text { filaments [42-44] }\end{array}$ \\
\hline LGMD R18 (LGMD2S) & TRAPPC11 [45] & Trafficking protein particle complex 11 & Golgi apparatus & $\begin{array}{l}\text { Intracellular vesicle } \\
\text { trafficking }\end{array}$ \\
\hline LGMD R19 (LGMD2T) & GMPPB [46] & GDP-mannose pyrophosphorylase B & Cytosol & Glycosylation \\
\hline LGMD R20 (LGMD2U) & $\begin{array}{l}\text { ISPD/CRPPA } \\
{[47]}\end{array}$ & CDL-L-ribitol pyrophosphorylase A & Cytosol & Glycosylation \\
\hline LGMD R21 (LGMD2Z) & POGLUT1 [48] & Protein O-glucosyltransferase 1 & $\begin{array}{l}\text { Endoplasmic } \\
\text { reticulum }\end{array}$ & Notch signaling \\
\hline LGMD R22 (none) & $\begin{array}{l}\text { COL6A1 } \\
\text { COL6A2 } \\
\text { COL6A3 }\end{array}$ & $\begin{array}{l}\text { Collagen } 6 a 1 \\
\text { Collagen } 6 a 2 \\
\text { Collagen } 6 a 3\end{array}$ & Extracellular matrix & $\begin{array}{l}\text { Regulation of satellite cell } \\
\text { self-renewal and muscle } \\
\text { regeneration [49] }\end{array}$ \\
\hline LGMD R23 (none) & LAMA2 & Laminin a2 & Extracellular matrix & $\begin{array}{l}\text { Regulation of autophagy-lysosome } \\
\text { pathway }[50,51]\end{array}$ \\
\hline LGMD R24 (none) & POMGNT2 & $\begin{array}{l}\text { Protein O-linked mannose N- } \\
\text { acetylglucosaminyltransferase } 2\end{array}$ & $\begin{array}{l}\text { Endoplasmic } \\
\text { reticulum }\end{array}$ & Glycosylation \\
\hline LGMD R25 (LGMD2X) & BVES [52] & Blood vessel epicardial substance & Sarcolemma & Membrane trafficking [52] \\
\hline $\begin{array}{l}\text { LGMD R, number } \\
\text { pending }\end{array}$ & $\begin{array}{l}\text { PYROXD1 }[53, \\
54]\end{array}$ & $\begin{array}{l}\text { Pyridine nucleotide-disulfide } \\
\text { oxidoreductase domain-containing protein } 1\end{array}$ & Nucleus & $\begin{array}{l}\text { Pyridine nucleotide-disulfide } \\
\text { reductase [55] }\end{array}$ \\
\hline
\end{tabular}

Many of the protein functions listed require further confirmation or are disputed

common disease mechanisms that cross multiple subtype boundaries, and effective molecular targets are likely to include genes that are not necessarily directly associated with LGMD subtypes.

\section{Functional clusters in LGMD}

Although clinical trials testing a variety of strategies are in progress, there are currently no FDA-approved, disease modifying therapies for any subtype of LGMD [120]. Even as LGMD-targeting gene replacement strategies likely reach approval over the coming years, there will remain LGMD subtypes with low numbers of patients, cohorts of patients with unknown mutations, and patients from a variety of subtypes for whom the potential benefits of a gene or mutation-specific therapy may never exceed the inherent risks associated with 
these methodologies. Those patients with moderate disease phenotypes regardless of the underlying causative gene mutation would likely fall into a category where there may be interest in testing a pharmacological treatment (that could be halted) but reduced interest in a more permanent experimental strategy. For all of the above-mentioned reasons, the identification of unifying therapeutic targets applicable to multiple subtypes of LGMDs is highly desirable.

To identify such targets, we should first consider the question: What binds all of these LGMDs together? The two core phenotypic features are progressive proximal muscle weakness, along with characteristic signs of muscle fiber destruction on biopsy, referred to as "dystrophic" features. Nuances in clinical presentation have helped to distinguish some of the LGMDs, such as the frequent occurrence of difficulty walking on tiptoes in LGMD R2 (LGMD2B), caused by dysferlin deficiency. However, heterogeneity associated with variable ages of onset and ranges of severity makes it generally difficult to distinguish and diagnose LGMD subtypes based on clinical presentation alone. A change in perspective is in order to aid in understanding disease pathways responsible for clinical features even when the genetic mutation is unknown. Further, given the large number of genespecific LGMD subtypes, it could very well be that several major disease mechanisms may be shared across the family of diseases. Yet despite careful studies that have collectively determined the cellular localization of most proteins associated with LGMD (Fig. 1), there is limited knowledge of potentially unifying molecular disease mechanisms. We assert that the identification of functional clusters of these proteins, grouped by such common mechanisms, will streamline our understanding of the disease processes and identify therapeutic targets relevant to individuals in multiple disease subgroups, including individuals whose pathogenic mutations have not been found. By extension, this approach may serve as a tool to not only find common mechanisms, but may also help to distinguish LGMD subtypes that do not share similar functional patterns, and afford further refinement of potential treatments.

Even though genetic mutations causing LGMD encode a diverse array of proteins (Tables 1 and 2), it is likely that additional functional clusters exist within the LGMD population. A review of the LGMD literature strongly suggests that two potential novel clusters of LGMD focus on defects of mechanical signal transduction and mitochondrial function. As described in the following sections, the mechanical signal transduction cluster may represent a pathway that triggers a maladaptive cascade with each contraction. In contrast, the mitochondrial function cluster may represent a common cellular response to disrupted homeostasis arising through many different triggers, including aberrant mechanical signaling.

\section{Glycosylation of dystroglycan proteins}

The functional cluster that is by far the most fully developed encompasses the dystroglycanopathies. Diseases in this family are bound together by impaired glycosylation of dystroglycans. Genetic mutations that impair this process have been found in a number of genes encoding enzymes, localized primarily at the Golgi apparatus and sarcoplasmic reticulum, that contribute to the normal process of dystroglycan glycosylation (Fig. 1). These genes include FKRP, POMT1, FKTN, POMT2, POMGnT1, ISPD, POMGNT2, and GMPPB (Table 1). These genes were first associated with severe forms of congenital muscular dystrophy, a related yet distinct category of muscular dystrophy, and then subsequently also associated with milder forms of dystroglycanopathy that met phenotypic criteria for LGMD. The corresponding encoded enzymes fukutin-related protein [29], protein O-mannosyltransferase 1 [121], fukutin [122], protein O-mannosyltransferase 2 [123], protein O-linked mannose $\mathrm{N}$-acetylglucosaminyltransferase 1 [124], CDL-Lribitol pyrophosphorylase A $[125,126]$, protein O-linked mannose $\mathrm{N}$-acetylglucosaminyltransferase 2 [127], and GDP-mannose pyrophosphorylase B [46] contribute to the

Table 2 Dominant forms of LGMD, listed according to the new 2018 classification system [13], with old subtype nomenclature in parentheses

\begin{tabular}{|c|c|c|c|c|}
\hline Subtype & Gene & Protein & Cellular localization & Protein function \\
\hline LGMD D1 (LGMD1D) & DNAJB6 $[56,57]$ & DNAJB6 & $\begin{array}{l}\text { Nucleus (DNAJB6a) [58] } \\
\text { Sarcoplasm (DNAJB6b) [58] }\end{array}$ & Z disc organization [58] \\
\hline LGMD D2 (LGMD1F) & TNPO3 $[59,60]$ & Transportin 3 & Nuclear membrane & $\begin{array}{l}\text { Transports serine/arginine-rich } \\
\text { proteins into nucleus }[61,62]\end{array}$ \\
\hline LGMD D3 (LGMD1G) & HNRNPDL [63] & $\begin{array}{l}\text { Heterogeneous nuclear } \\
\text { ribonucleoprotein D-like }\end{array}$ & Nucleus [63] & RNA processing [63] \\
\hline LGMD D4 (LGMD1I) & CAPN3 & Calpain 3 & Myofibril & Cysteine protease \\
\hline LGMD D5 & $\begin{array}{l}\text { COL6A1 } \\
\text { COL6A2 } \\
\text { COL6A3 }\end{array}$ & $\begin{array}{l}\text { Collagen } 6 a 1 \\
\text { Collagen } 6 a 2 \\
\text { Collagen } 6 a 3\end{array}$ & Extracellular matrix & $\begin{array}{l}\text { Regulation of satellite cell } \\
\text { self-renewal and muscle } \\
\text { regeneration [49] }\end{array}$ \\
\hline
\end{tabular}




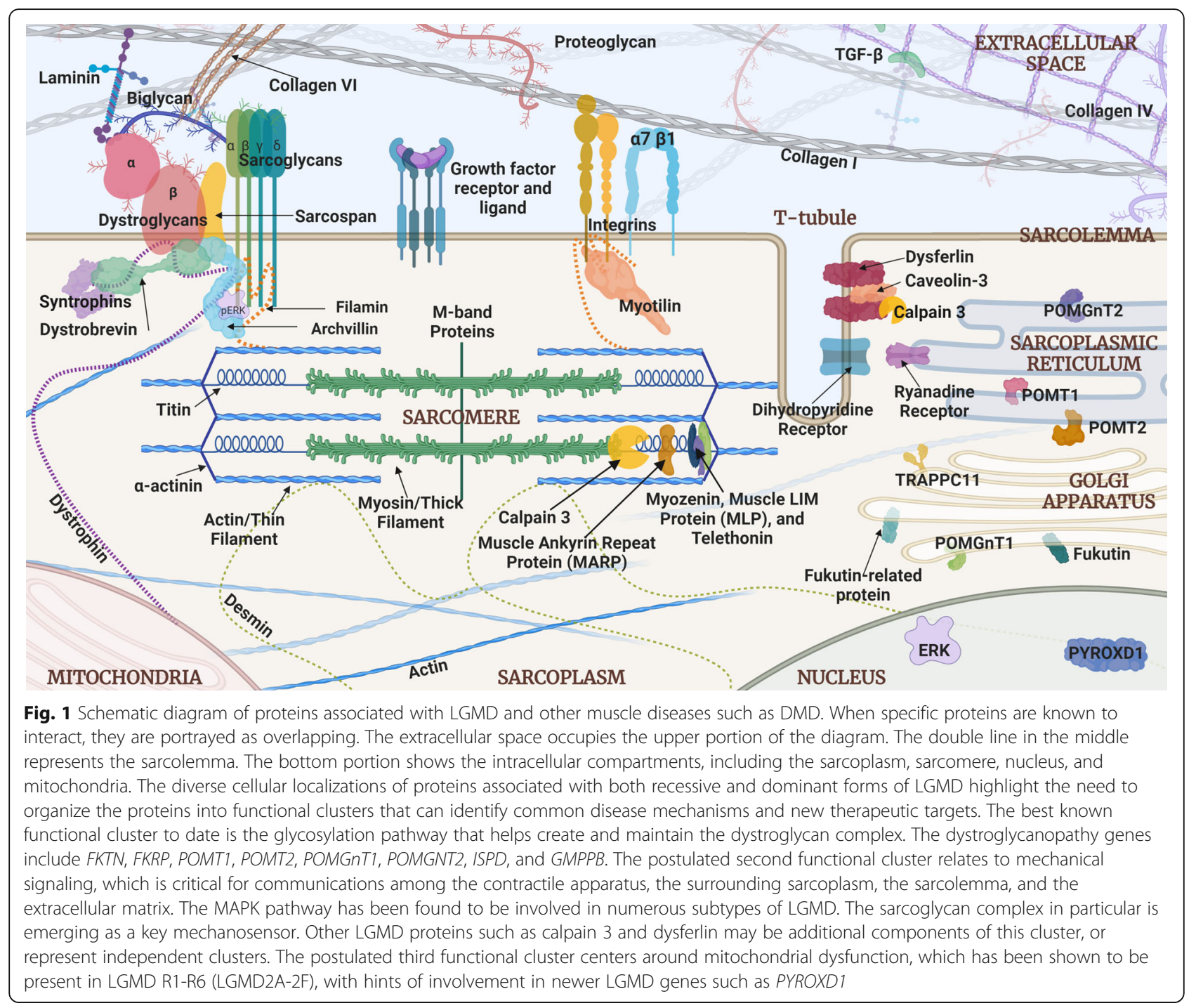

process of O-mannosyl glycosylation of $\alpha$-dystroglycan before it is transported to the sarcolemma.

Knowledge of the dystroglycanopathies has advanced to the point where experiments have studied the possibility of targeting multiple disease subtypes. One such therapeutic strategy is to overexpress $L A R G E$, a dystroglycanopathy gene (currently associated only with a congenital muscular dystrophy phenotype) that induces hyperglycosylation of $\alpha$-dystroglycan; this approach has augmented glycosylation in mouse models of two other dystroglycanopathies, FKTN deficiency and POMGnT1 deficiency; these latter two genes have been associated with LGMD as well as congenital muscular dystrophy [128]. Another study demonstrated the therapeutic potential of overexpressing ISPD in FKRP mutant mice [129]. These investigations support the concept that targeting specific components of the glycosylation pathway shared within this functional cluster could provide therapeutic benefit for multiple LGMD subtypes.

\section{Mechanical signaling defects in LGMD}

Skeletal muscle adaptation can occur through changes in active or passive workload converging into final common pathways. During active force generation, multiple signals alter in parallel, including mechanical deformation, phosphorylation patterns, calcium ion fluxes, and local concentration (depletion) of high-energy substrates. Distinct patterns in the MAP kinase family of proteins are evident in healthy tissue in response to active lengthening contractions. In one of the first studies examining this phenomenon, Martineau and Gardiner established a dose response of MAPK phosphorylation with respect to strain and implicated Jnk as the most responsive MAPK to active strain, with ERK1/2 responsive to both active and passive tension, and p38 being relatively insensitive to mechanical deformation [130]. Passive stretch instigates signal transduction within muscle, such as transient induction of the p70S6K pathway [131, 132], but because the energetic cost of active contraction is 
eliminated, the responses may provide insight into signaling that is more closely aligned with mechanical deformation. Signaling defects are evident in multiple pathways and across many dystrophies. Aberrant signaling is a feature of dystrophic muscle which occurs at rest, during active force generation, and passive movement [131, 133-139], summarized in Table 3.

A key contributor to mechanosensing is the sarcoglycan complex. The discovery of $\alpha$-SG (Sgca) and $\gamma$-SG (Sgcg) phosphorylation in response to adhesion of cultured cells led to the proposal that the SG sub-complex regulates mechanosensing [152]. We, and others, have proposed that the SG complex is a critical part of the mechanical signaling machinery and that absence of this complex alters signaling [131, 133, 153, 154]. In a mouse model for LGMD R5 (LGMD2C), ablation of Sgcg causes severe pathology, yet there is little mechanical fragility [155]. However, distinct hyper-signaling through ERK1/2 occurs at rest and with active eccentric contractions with loss of Sgcg [133]. Mechanosignaling may not only originate in the complex but also in modifiers the complex: tyrosine phosphorylation of Sgcg occurs following active and passive strain changes in the muscle
[131, 134], and the loss of Sgcg phosphorylation also alters the mechanical response even when the complex is otherwise intact [134]. Indeed, the fact that this residue, as well as others in the intracellular domain, has been associated with severe autosomal recessive muscular dystrophy (https://www.ncbi.nlm.nih.gov/clinvar/?term= Sgcg\%5Bgene\%5D) point to this region of Sgcg as critical for function. With this in mind, it suggests that proteins involved in modulating the phosphorylation state of the sarcoglycans may also be candidates for LGMD causing mutations or modifiers of the severity of the symptoms.

In contrast to ERK and Jnk, p38 appears relatively insensitive to strain, yet it may still serve as an indication of disease. Activation of alpha and beta isoforms of p38, in particular, are critical regulators of myoblast differentiation [156, 157], hence reduced p38 activity may lead to defects in muscle cell maturation or in regeneration and growth. In addition, p38 is activated during sustained muscle activity, and is one of the upstream triggers for transcription of PPAR $\gamma$ coactivator (PGC)-1, and ultimately mitochondrial biogenesis [158]. Thus, abnormal p38 activity may also underlie maladaptation associated with neuromuscular disease. Both consequences

Table 3 MAPK pathway phosphorylation changes associated with mechanical perturbation and neuromuscular diseases in skeletal muscle

\begin{tabular}{|c|c|c|c|}
\hline Pathway & Disease & Finding & Citations \\
\hline \multirow{3}{*}{$\begin{array}{l}\text { Jnk (Thr183/ } \\
\text { Tyr195) }\end{array}$} & Healthy & Jnk activation directly correlated to active tension but not passive tension. P54 is most sensitive & [130] \\
\hline & Healthy & Resistance exercise stimulates P-JNK & [140] \\
\hline & $\mathrm{DMD}(m d x)$ & $\begin{array}{l}\text { Elevated P-JNK1 associated with pathology (all refs). JNK1 inhibition by JIP1 attenuates pathology; } \\
\text { P54 > p46 in phosphorylation status; Murine diaphragm highest elevation [141]. p46 > p54 in } \\
\text { phosphorylation status [142] }\end{array}$ & $\begin{array}{l}{[131,141,} \\
142]\end{array}$ \\
\hline \multirow{7}{*}{$\begin{array}{l}\text { p38 (Thr180/ } \\
\text { Tyr182) }\end{array}$} & Healthy & Phosphorylated p38 is not sensitive to tension & [130] \\
\hline & LGMD2C $\left(\mathrm{SgCg}^{-1-}\right)$ & Stretched myotubes have elevated p-p38 & [143] \\
\hline & FSHD & P38 inhibition reduces DUX4 expression & [144] \\
\hline & LGMD2B (SJL) & Reduction of P-p38 by paloxamer188 but no comparison to wildtype mice & [145] \\
\hline & $\mathrm{DMD}(m d x)$ & Loss of MKP5 improves phenotype & [146] \\
\hline & $\begin{array}{l}\operatorname{LGMD} 2 \mathrm{~F}\left(\mathrm{Sgcd}^{-1-}\right) \\
\mathrm{DMD}(m d x)\end{array}$ & $\begin{array}{l}\text { Elevated p38 associated with pathology; transgenic ablation of p38a (mapk14) reduces } \\
\text { pathology; }\end{array}$ & [147] \\
\hline & LGMD2A (C3KO) & Suppressed in sedentary and run conditions & [148] \\
\hline \multirow{8}{*}{$\begin{array}{l}\text { ERK1/2 } \\
\text { (Thr202/ } \\
\text { Tyr204) }\end{array}$} & Healthy & Erk phosphorylation correlated with both active and passive tension & [130] \\
\hline & $\mathrm{DMD}(m d x)$ & Elevated in resting diaphragm, with stretch-dependent enhancement & [149] \\
\hline & LGMD2C $\left(\mathrm{SgCg}^{-1-}\right)$ & Stretched myotubes have elevated P-ERK1/2 & [143] \\
\hline & LGMD2C $\left(\mathrm{Sgcg}^{-1-}\right)$ & Resting elevated P-ERK1/2 & $\begin{array}{l}{[133,} \\
134]\end{array}$ \\
\hline & LGMD2C $\left(\mathrm{SgCg}^{-/-}\right)$ & Sustained levels with contraction but not passive stretch & $\begin{array}{l}{[131,} \\
134]\end{array}$ \\
\hline & $\begin{array}{l}\operatorname{DMD}(m d x) \\
\operatorname{LGMD} 2 \mathrm{C}\left(\mathrm{Sgcg}^{-1-}\right)\end{array}$ & $\begin{array}{l}\text { Uncoupling of mechano-signaling. Elevated P-ERK1/2 in human biopsies of LGMD2C/2E and } \\
\text { DMD }\end{array}$ & [136] \\
\hline & LGMD2C & Dusp6 (ERK phosphatase) genetic modifier & [150] \\
\hline & LGMD2F $\left(\mathrm{Sgcd}^{-1-}\right)$ & $\begin{array}{l}\text { Increased ERK1/2 protects against dystrophy with fast-to-slow fiber type shift; selective ablation } \\
\text { of ERK1 }\end{array}$ & [151] \\
\hline
\end{tabular}


of reduced P-p38 are evident in mice lacking calpain 3 (the protein deficient in LGMD R1 (LGMD2A)). The adaptational response of calpain 3 null mice to exercise training was blunted and associated with diminished Pp38 as well as CAMKII signaling, implicating calpain 3 as an upstream regulator of these signaling pathways [159]. Further, regenerative capacity and recovery from disuse atrophy are also delayed [160, 161]. Even though p38 activity may be depressed with the loss of calpain 3, one cannot extend that disruption to other MAPK proteins, or to aberrant mechanosignaling, and there is no evidence to date to address this possibility.

Not only are there LGMD subtypes with low p38 activity, several studies have demonstrated heightened p38 phosphorylation in mouse and cell models for LGMD R2 (LGMD2B), LGMD R5 (LGMD2C), and LGMD R6 (LGMD2F), as well as facioscapulohumeral muscular dystrophy (FSHD) and DMD [143, 144, 147]. Further suppression of P-p38 ameliorated histopathology in several of these disease models [144, 147], yet disinhibition of p38 activity through ablation of the phosphatase, MKP5/Dusp10 also benefited $m d x$ muscle [146]. The dichotomy in the direction of aberrant signaling suggests that this pathway must be properly tuned in healthy muscle, but also may serve as a discriminating feature for the specific genetic defect. Namely, defects in the sarcoglycan complex and its associated proteins may share elevated P-p38, whereas defects that are associated with reduced calcium-mediated actions, such as with calpain 3 mutations, may have reduced P-p38. By extension, heightened calcium entry may also exhibit higher P-p38 levels.

How are these LGMD-dependent signaling defects different from aberrant signaling associated with other classes of muscular dystrophies? The loss of dystrophin in DMD also displays aberrant signaling in the MAPK pathways [141, 147, 149]. A common link to a subset of LGMDs is the secondary loss of the sarcoglycan and dystroglycan complexes in DMD, potentially implicating these subcomplexes as the underlying cause of the signaling defects. However, loss of dystrophin is also accompanied by mechanical fragility of the muscle, and this could also contribute to altered signaling. Hence, the separation of mechanical fragility from disrupted mechanical signaling is an important criterion to its identity as a functional cluster.

\section{Mitochondrial dysfunction in LGMD}

An LGMD functional cluster that is based upon mitochondrial function may also help to explain in part the observed variations in age of onset, speed of progression, and overall severity that can vary between patients even when the underlying causative gene is the same [162-164]. This may occur through altered energy production, impaired $\mathrm{Ca}^{2+}$ homeostasis, activation of apoptosis, a combination of these, or currently unknown roles for mitochondria in LGMD pathophysiology. Thus far, studies have demonstrated altered mitochondrial function in 6 LGMD subtypes (Table 4), and in one example, variations in mitochondrial-mediated apoptosis due to altered expression of the pro-survival protein BCL2 correlated with disease severity in patients homozygous for the same SGCG mutation (LGMD R5, also known as LGMD2C) [53, 147, 163, 165-169]. In sum, these studies strongly suggest that (1) mitochondria impart a key contribution to the pathophysiology of LGMD presentation, and (2) this aspect of dysfunction in LGMD should be more thoroughly investigated across subtypes and individuals to understand which aspects of mitochondrial function are the most viable therapeutic targets.

With respect to mitochondrial dysfunction, there is solid evidence from prior work suggesting the presence of mitochondrial dysfunction in several subtypes of LGMD. However, there is no prior research exploring the hypothesis that different forms of mitochondrial dysfunction can help explain the spectrum of phenotypic severity in different subtypes of LGMD. Thus far, no study has systematically examined a thorough panel of mitochondria-related assessments in multiple forms of LGMD. Such studies would enable more optimal selection of patients most likely to benefit from potential mitochondria-targeting treatment strategies based upon their mitochondrial function profile.

\section{Complementary disease mechanisms and implications for therapy}

As noted above, multiple studies indicate that both mechanosignaling and mitochondrial dysfunction contribute to the disease mechanisms of LGMD R1 (LGMD2A), LGMDR5 (LGMD2C), and LGMD R6 (LGMD2F), caused by recessive mutations in $C A P N 3, S G C G$, and $S G C D$, respectively. It is expected that these two functional clusters, along with glycosylation defects, intersect at various points in their pathways. The interactions among these three have not been explored in depth in prior work, and such explorations would be expected to be quite fruitful with respect to understanding the overall LGMD disease process better. Importantly, the pathways involved in each of these functional clusters can provide parallel evaluation of potential therapeutics, as well as how modulation of one pathway may alter aspects of others.

Genetic and pharmacologic modulation of mechanosignaling and mitochondrial function support the possibility for these functional clusters to become therapeutic targets. The rationale stems from either preventing upstream triggers, such as mechanosignaling, to become pathogenic, or shoring up muscles against the 
Table 4 Mitochondrial evaluations of LGMDs in literature: listing of mitochondrial assessments and status of these readouts in current LGMD literature

\begin{tabular}{|c|c|}
\hline Functional measurement: & Reported analyses in LGMD literature: \\
\hline Activation of intrinsic apoptotic pathways & $\begin{array}{l}\text { - Variability in LGMD R5 (LGMD2C) patient severity based upon BCL2 } \\
\text { expression levels in skeletal muscle [163] } \\
\text { - No activation in aged LGMD R6 (LGMD2F) cardiomyocytes [165] }\end{array}$ \\
\hline Mitochondrial ultrastructure & $\begin{array}{l}\text { - Mitochondrial swelling in LGMD R6 (LGMD2F) cardiomyocytes [165] } \\
\text { - Mitochondrial swelling and disorganized structure in LGMD R1 } \\
\text { (LGMD2A) patient skeletal muscle [166] } \\
\text { - Mitochondrial swelling in LGMD R6 (LGMD2F) [147, 167] } \\
\text { - Reduced mitochondrial cristae density in LGMD R3 (LGMD2D) [168] }\end{array}$ \\
\hline Oxygen consumption & $\begin{array}{l}\text { - Reduced in LGMD R3 (LGMD2D) patient and mouse skeletal muscle [168] } \\
\text { - Reduced in PYROXD1 knockdown myoblasts [53] }\end{array}$ \\
\hline $\begin{array}{l}\text { Mitochondrial membrane potential/permeability } \\
\text { transition pore (mPTP) status }\end{array}$ & • Decreased potential and open mPTP in LGMD R6 (LGMD2F) [165] \\
\hline Electron transport chain (ETC) expression & $\begin{array}{l}\text { - Altered Cl and CIV expression in LGMD R2 (LGMD2B) patient muscle [169] } \\
\text { - Decreased ETC expression in LGMD R3 (LGMD2D) mouse diaphragm } \\
\text { muscle [168] } \\
\text { - Decreased CV expression in LGMD R6 (LGMD2F) mouse skeletal muscle } \\
\text { and heart [170] }\end{array}$ \\
\hline mtDNA copy numbers & - Reduced in LGMD R3 (LGMD2D) patient and mouse skeletal muscle [168] \\
\hline Mitochondrial biogenesis & $\begin{array}{l}\text { - Defective mitochondrial biogenesis in LGMD R3 (LGMD2D) patient and } \\
\text { mouse skeletal muscle [168] }\end{array}$ \\
\hline Mitochondrial $\mathrm{Ca}^{2+}$ uptake & - $\mathrm{Ca}^{2+}$ overload in LGMD R6 (LGMD2F) cardiomyocytes [165] \\
\hline
\end{tabular}

downstream consequences, such as mitochondrial uncoupling. For example, inhibition of MAPK/ERK kinase led to alleviation of cardiac complications in a mouse model of laminA/C (LMNA) deficiency [171]. The MAPK pathway has been linked to mechanosignaling in muscle [130]. Metformin has been found to enhance autophagy and provide cardioprotection in a mouse model of $\delta$ sarcoglycan (SGCD) deficiency, associated with LGMD R6 (LGMD2F) [172]. The therapeutic effect of metformin in this context appears to arise at least in part from stimulation of mitophagy [173]. Targeting cyclophilin D through Debio 025 also appears to inhibit mitochondria-mediated necrosis in multiple mouse models of muscular dystrophy $[167,174]$. These studies hint at the enormous untapped potential of targeting shared disease pathways. However, as these targets are in all cells, the balance between benefit to muscle and detriment to other tissues must be addressed.

\section{Concluding section}

Molecular therapies for selected subtypes of LGMD will almost certainly be approved for clinical use in the next several years, mirroring the revolutionary developments in other neuromuscular diseases. However, the genetic diversity of this disease group and the large number of patients without genetic diagnoses suggest that two parallel tracks of therapeutic development are needed: (1) gene-specific and even mutation-specific precision therapies and (2) broader therapies that target common downstream pathways. Several lines of investigation will enhance the development of the latter: (1) in depth evaluation of existing and new disease models to seek transcriptomic, proteomic, and functional evidence for associations with the postulated functional clusters; (2) exploration of promising model systems such as 3-dimensional scaffolds and Drosophila that are underutilized in the study of LGMD, with examinations of both mechanistic and therapeutic questions; (3) elucidation of the genetic etiologies of individuals affected by LGMD who do not have easily identifiable pathogenic mutations; (4) more precise replication of common and biologically pivotal disease mutations across the spectrum of LGMD subtypes. Further elucidation of disease mechanisms for LGMD will facilitate the development of an array of sophisticated therapeutic approaches that will have a significant beneficial impact on the broadest possible spectrum of patients with this disease.

\footnotetext{
Abbreviations

AAV: Adeno-associated virus; ANO5: Anoctamin-5; BCL2: B cell lymphoma 2; CAPN3: Calpain 3; DMD: Duchenne muscular dystrophy; DYSF: Dysferlin; ERK1/2: Extracellular regulated kinases (MAPK1); FDA: Food and Drug Administration; FKRP: Fukutin-related protein; FKTN: Fukutin; iPSCs: Induced pluripotent stem cells; ISPD/CRPPA: Isoprenoid synthase domain-containing protein/cytidylyltransferase-like protein-ribitol pyrophosphorylase A; Jnk: cJun N-terminal kinase (MAPK8); LARGE: Xylosyl- and glucuronyltransferase 1; LGMD: Limb-girdle muscular dystrophy; MAPK: Mitogen-activated protein kinase; MG53: Mitsugumin-53; tripartite motif-containing 72 (TRIM72); p38: p38 MAPK (MAPK14); p70S6K: Ribosomal protein S6 kinase beta-1 (S6K1); POMGnT1: Protein O-linked mannose N-acetylglucosaminyltransferase 1; POMGNT2: Protein O-linked mannose $\mathrm{N}$-acetylglucosaminyltransferase 2; POMT1: Protein O-mannosyltransferase 1; POMT2: Protein Omannosyltransferase 2; SGCA and Sgca: Alpha-sarcoglycan; SGCB: Beta-
} 
sarcoglycan; SGCD: Delta-sarcoglycan; SGCG and Sgcg: Gamma-sarcoglycan; SMA: Spinal muscular atrophy

\section{Acknowledgements}

Not applicable

\section{Authors' contributions}

ERB and CAP conceptualized the manuscript, drafted portions of the text, and critically reviewed and edited the manuscript. WLS critically reviewed and edited the manuscript, and contributed a key figure. PBK conceptualized and designed the manuscript, drafted portions of the text, and critically reviewed and edited the manuscript. All authors read and approved the final manuscript.

\section{Funding}

This work was supported by NIH R01 AR069660 (ERB) and the Children's Miracle Network (CAP and PBK).

\section{Availability of data and materials}

Not applicable. All data is compiled from previously published work

\section{Ethics approval and consent to participate}

Not applicable

\section{Consent for publication}

Not applicable

\section{Competing interests}

PBK consults for AveXis, receives honoraria from Wiley for serving as associate editor of Muscle \& Nerve, and receives royalties from Wolters Kluwer for authoring topics for UpToDate.

\section{Author details}

${ }^{1}$ Center for Exercise Science, Department of Applied Physiology and Kinesiology, University of Florida College of Health and Human Performance, Gainesville, FL, USA. '2Myology Institute, University of Florida, Gainesville, FL, USA. ${ }^{3}$ Department of Pediatrics, University of Florida College of Medicine, Gainesville, FL, USA. ${ }^{4}$ Department of Chemical Engineering, University of Florida Herbert Wertheim College of Engineering, Gainesville, FL, USA. ${ }^{5}$ Division of Pediatric Neurology, Department of Pediatrics, University of Florida College of Medicine, PO Box 100296, Gainesville, FL 32610, USA. ${ }^{6}$ Department of Neurology, University of Florida College of Medicine, Gainesville, FL, USA. 7 Department of Molecular Genetics and Microbiology, University of Florida College of Medicine, Gainesville, FL, USA. ${ }^{8}$ Genetics Institute, University of Florida, Gainesville, FL, USA.

Received: 25 May 2020 Accepted: 16 July 2020

Published online: 29 July 2020

\section{References}

1. Monaco AP, et al. Isolation of candidate CDNAs for portions of the Duchenne muscular dystrophy gene. Nature. 1986;323:646-50. https://doi. org/10.1038/323646a0

2. Hoffman EP, Brown RH Jr, Kunkel LM. Dystrophin: the protein product of the Duchenne muscular dystrophy locus. Cell. 1987:51:919-28. https://doi. org/10.1016/0092-8674(87)90579-4.

3. Lefebvre $\mathrm{S}$, et al. Identification and characterization of a spinal muscular atrophy-determining gene. Cell. 1995;80:155-65. https://doi.org/10.1016/ 0092-8674(95)90460-3.

4. Ryder S, et al. The burden, epidemiology, costs and treatment for Duchenne muscular dystrophy: an evidence review. Orphanet J Rare Dis. 2017;12:79. https://doi.org/10.1186/s13023-017-0631-3.

5. Mostacciuolo ML, Danieli GA, Trevisan C, Muller E, Angelini C. Epidemiology of spinal muscular atrophies in a sample of the Italian population. Neuroepidemiology. 1992;11:34-8. https://doi.org/10.1159/000110905.

6. Verhaart IEC, et al. A multi-source approach to determine SMA incidence and research ready population. J Neurol. 2017;264:1465-73. https://doi.org/ 10.1007/s00415-017-8549-1.

7. Pacak CA, Kang PB. The end of the beginning: the journey to molecular therapies for spinal muscular atrophy. Pediatr Neurol. 2020;102:1-2. https:// doi.org/10.1016/j.pediatrneurol.2019.07.018.
8. Lowes LP, et al. Impact of age and motor function in a phase $1 / 2 \mathrm{~A}$ study of infants with SMA type 1 receiving single-dose gene replacement therapy. Pediatr Neurol. 2019;98:39-45. https://doi.org/10.1016/j.pediatrneurol.2019. 05.005 .

9. Mah JK, et al. A systematic review and meta-analysis on the epidemiology of the muscular dystrophies. Can J Neurol Sci. 2016:43:163-77. https://doi. org/10.1017/cjn.2015.311

10. Norwood FL, et al. Prevalence of genetic muscle disease in northern England: in-depth analysis of a muscle clinic population. Brain. 2009;132: 3175-86. https://doi.org/10.1093/brain/awp236.

11. Do TN, et al. Muscular dystrophy surveillance, tracking, and research network pilot: population-based surveillance of major muscular dystrophies at four U.S. sites, 2007-2011. Birth Defects Res. 2018:110:1404-11. https://doi. org/10.1002/bdr2.1371

12. Petersen JA, et al. Dysferlinopathy in Switzerland: clinical phenotypes and potential founder effects. BMC Neurol. 2015;15:182. https://doi.org/10.1186/ s12883-015-0449-3.

13. Straub V, Murphy A, Udd B, LGMD Workshop Study Group. 229th ENMC international workshop: limb girdle muscular dystrophies - nomenclature and reformed classification Naarden, the Netherlands, 17-19 march 2017. Neuromuscul Disord. 2018:28:702-10. https://doi.org/10.1016/.nmd.2018.05.007.

14. Richard I, et al. Mutations in the proteolytic enzyme calpain 3 cause limbgirdle muscular dystrophy type 2A. Cell. 1995;81:27-40. https://doi.org/10. 1016/0092-8674(95)90368-2.

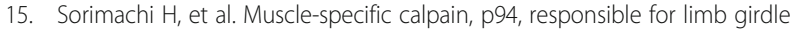
muscular dystrophy type 2A, associates with connectin through IS2, a p94specific sequence. J Biol Chem. 1995;270:31158-62. https://doi.org/10.1074/ jbc.270.52.31158.

16. Bashir $\mathrm{R}$, et al. A gene related to Caenorhabditis elegans spermatogenesis factor fer-1 is mutated in limb-girdle muscular dystrophy type 2B. Nat Genet. 1998;20:37-42. https://doi.org/10.1038/1689.

17. Liu J, et al. Dysferlin, a novel skeletal muscle gene, is mutated in Miyoshi myopathy and limb girdle muscular dystrophy. Nat Genet. 1998;20:31-6. https://doi.org/10.1038/1682.

18. Bansal D, et al. Defective membrane repair in dysferlin-deficient muscular dystrophy. Nature. 2003:423:168-72. https://doi.org/10.1038/nature01573.

19. Lennon $\mathrm{NJ}$, et al. Dysferlin interacts with annexins $\mathrm{A} 1$ and $\mathrm{A} 2$ and mediates sarcolemmal wound-healing. J Biol Chem. 2003;278:50466-73. https://doi. org/10.1074/jbc.M307247200

20. Piccolo F, et al. Primary adhalinopathy: a common cause of autosomal recessive muscular dystrophy of variable severity. Nat Genet. 1995;10:243-5. https://doi.org/10.1038/ng0695-243.

21. Bonnemann CG, et al. Beta-sarcoglycan (A3b) mutations cause autosomal recessive muscular dystrophy with loss of the sarcoglycan complex. Nat Genet. 1995;11:266-73. https://doi.org/10.1038/ng1195-266.

22. Lim LE, et al. Beta-sarcoglycan: characterization and role in limb-girdle muscular dystrophy linked to 4q12. Nat Genet. 1995;11:257-65. https://doi. org/10.1038/ng1195-257

23. Noguchi $\mathrm{S}$, et al. Mutations in the dystrophin-associated protein gammasarcoglycan in chromosome 13 muscular dystrophy. Science. 1995;270:81922. https://doi.org/10.1126/science.270.5237.819.

24. Nigro V, et al. Autosomal recessive limb-girdle muscular dystrophy, LGMD2F is caused by a mutation in the delta-sarcoglycan gene. Nat Genet. 1996;14: 195-8. https://doi.org/10.1038/ng1096-195.

25. Moreira ES, et al. Limb-girdle muscular dystrophy type $2 \mathrm{G}$ is caused by mutations in the gene encoding the sarcomeric protein telethonin. Nat Genet. 2000;24:163-6. https://doi.org/10.1038/72822.

26. Sadikot T, Hammond CR, Ferrari MB. Distinct roles for telethonin N-versus Cterminus in sarcomere assembly and maintenance. Dev Dyn. 2010;239: 1124-35. https://doi.org/10.1002/dvdy.22263.

27. Frosk $\mathrm{P}$, et al. Limb-girdle muscular dystrophy type $2 \mathrm{H}$ associated with mutation in TRIM32, a putative E3-ubiquitin-ligase gene. Am J Hum Genet. 2002;70:663-72. https://doi.org/10.1086/339083.

28. Kudryashova E, Kudryashov D, Kramerova I, Spencer MJ. Trim32 is a ubiquitin ligase mutated in limb girdle muscular dystrophy type $2 \mathrm{H}$ that binds to skeletal muscle myosin and ubiquitinates actin. J Mol Biol. 2005; 354:413-24. https://doi.org/10.1016/j.jmb.2005.09.068

29. Brockington $M$ et al. Mutations in the fukutin-related protein gene (FKRP) identify limb girdle muscular dystrophy 21 as a milder allelic variant of congenital muscular dystrophy MDC1C. Hum Mol Genet. 2001:10:2851-9. https://doi.org/10.1093/hmg/10.25.2851. 
30. Hackman P, et al. Tibial muscular dystrophy is a titinopathy caused by mutations in TTN, the gene encoding the giant skeletal-muscle protein titin. Am J Hum Genet. 2002;71:492-500. https://doi.org/10.1086/342380.

31. Eilertsen KJ, Kazmierski ST, Keller TC 3rd. Cellular titin localization in stress fibers and interaction with myosin II filaments in vitro. J Cell Biol. 1994;126: 1201-10. https://doi.org/10.1083/jcb.126.5.1201.

32. Balci B, et al. An autosomal recessive limb girdle muscular dystrophy (LGMD2) with mild mental retardation is allelic to Walker-Warburg syndrome (WWS) caused by a mutation in the POMT1 gene. Neuromuscul Disord. 2005;15:271-5. https://doi.org/10.1016/j.nmd.2005.01.013.

33. Bolduc $V$, et al. Recessive mutations in the putative calcium-activated chloride channel anoctamin 5 cause proximal LGMD2L and distal MMD3 muscular dystrophies. Am J Hum Genet. 2010;86:213-21. https://doi.org/10. 1016/j.ajhg.2009.12.013

34. Murakami T, et al. Fukutin gene mutations cause dilated cardiomyopathy with minimal muscle weakness. Ann Neurol. 2006;60:597-602. https://doi. org/10.1002/ana.20973.

35. Godfrey $C$, et al. Fukutin gene mutations in steroid-responsive limb girdle muscular dystrophy. Ann Neurol. 2006;60:603-10. https://doi.org/10.1002/ ana.21006.

36. Biancheri R, et al. POMT2 gene mutation in limb-girdle muscular dystrophy with inflammatory changes. Biochem Biophys Res Commun. 2007;363:10337. https://doi.org/10.1016/j.bbrc.2007.09.066.

37. Clement EM, et al. Mild POMGnT1 mutations underlie a novel limb-girdle muscular dystrophy variant. Arch Neurol. 2008;65:137-41. https://doi.org/10. 1001/archneurol.2007.2.

38. Godfrey C, et al. Refining genotype phenotype correlations in muscular dystrophies with defective glycosylation of dystroglycan. Brain. 2007;130: 2725-35. https://doi.org/10.1093/brain/awm212.

39. Hara $Y$, et al. A dystroglycan mutation associated with limb-girdle muscular dystrophy. N Engl J Med. 2011;364:939-46. https://doi.org/10.1056/ NEJMoa1006939.

40. Rader EP, et al. Role of dystroglycan in limiting contraction-induced injury to the sarcomeric cytoskeleton of mature skeletal muscle. Proc Natl Acad Sci U S A. 2016;113:10992-7. https://doi.org/10.1073/pnas. 1605265113.

41. Gundesli $\mathrm{H}$, et al. Mutation in exon if of PLEC, leading to disruption of plectin isoform 1f, causes autosomal-recessive limb-girdle muscular dystrophy. Am J Hum Genet. 2010;87:834-41. https://doi.org/10.1016/j.ajhg. 2010.10.017.

42. Winter $L$, et al. Chemical chaperone ameliorates pathological protein aggregation in plectin-deficient muscle. J Clin Invest. 2014;124:1144-57. https://doi.org/10.1172/JCl71919.

43. Wiche $G$, Winter $L$. Plectin isoforms as organizers of intermediate filament cytoarchitecture. Bioarchitecture. 2011;1:14-20. https://doi.org/10.4161/bioa. 1.1.14630.

44. Castanon MJ, Walko G, Winter L, Wiche G. Plectin-intermediate filament partnership in skin, skeletal muscle, and peripheral nerve. Histochem Cell Biol. 2013;140:33-53. https://doi.org/10.1007/s00418-013-1102-0.

45. Bogershausen $\mathrm{N}$, et al. Recessive TRAPPC11 mutations cause a disease spectrum of limb girdle muscular dystrophy and myopathy with movement disorder and intellectual disability. Am J Hum Genet. 2013;93:181-90. https://doi.org/10.1016/j.ajhg.2013.05.028.

46. Carss KJ, et al. Mutations in GDP-mannose pyrophosphorylase B cause congenital and limb-girdle muscular dystrophies associated with hypoglycosylation of alpha-dystroglycan. Am J Hum Genet. 2013;93:29-41. https://doi.org/10.1016/j.ajhg.2013.05.009.

47. Tasca G, et al. Limb-girdle muscular dystrophy with alpha-dystroglycan deficiency and mutations in the ISPD gene. Neurology. 2013;80:963-5. https://doi.org/10.1212/WNL.0b013e3182840cbc.

48. Servian-Morilla E, et al. A POGLUT1 mutation causes a muscular dystrophy with reduced notch signaling and satellite cell loss. EMBO Mol Med. 2016;8: 1289-309. https://doi.org/10.15252/emmm.201505815.

49. Urciuolo A, et al. Collagen VI regulates satellite cell self-renewal and muscle regeneration. Nat Commun. 2013;4:1964. https://doi.org/10.1038/ ncomms 2964

50. Carmignac V, Quere R, Durbeej M. Proteasome inhibition improves the muscle of laminin alpha2 chain-deficient mice. Hum Mol Genet. 2011;20: 541-52. https://doi.org/10.1093/hmg/ddq499.

51. Carmignac $V$, et al. Autophagy is increased in laminin alpha2 chain-deficient muscle and its inhibition improves muscle morphology in a mouse model of MDC1A. Hum Mol Genet. 2011;20:4891-902. https://doi.org/10.1093/ hmg/ddr427.

52. Schindler RF, et al. POPDC1(S201F) causes muscular dystrophy and arrhythmia by affecting protein trafficking. J Clin Invest. 2016;126:239-53. https://doi.org/10.1172/JCl79562.

53. Saha M, et al. Impact of PYROXD1 deficiency on cellular respiration and correlations with genetic analyses of limb-girdle muscular dystrophy in Saudi Arabia and Sudan. Physiol Genomics. 2018;50:929-39. https://doi.org/ 10.1152/physiolgenomics.00036.2018.

54. Sainio MT, et al. Recessive PYROXD1 mutations cause adult-onset limbgirdle-type muscular dystrophy. J Neurol. 2019;266:353-60. https://doi.org/ 10.1007/s00415-018-9137-8.

55. O'Grady GL, et al. Variants in the oxidoreductase PYROXD1 cause early-onset myopathy with internalized nuclei and myofibrillar disorganization. Am J Hum Genet. 2016;99:1086-105. https://doi.org/10.1016/j.ajhg.2016.09.005.

56. Sarparanta J, et al. Mutations affecting the cytoplasmic functions of the cochaperone DNAJB6 cause limb-girdle muscular dystrophy. Nat Genet. 2012; 44(450-455):S451-2. https://doi.org/10.1038/ng.1103.

57. Harms MB, et al. Exome sequencing reveals DNAJB6 mutations in dominantly-inherited myopathy. Ann Neurol. 2012;71:407-16. https://doi. org/10.1002/ana.22683.

58. Bengoechea R, Pittman SK, Tuck EP, True HL, Weihl CC. Myofibrillar disruption and RNA-binding protein aggregation in a mouse model of limb-girdle muscular dystrophy 1D. Hum Mol Genet. 2015;24:6588-602. https://doi.org/10.1093/hmg/ddv363.

59. Melia MJ, et al. Limb-girdle muscular dystrophy $1 \mathrm{~F}$ is caused by a microdeletion in the transportin 3 gene. Brain. 2013;136:1508-17. https:// doi.org/10.1093/brain/awt074.

60. Torella A, et al. Next-generation sequencing identifies transportin 3 as the causative gene for LGMD1F. PLoS One. 2013;8:e63536. https://doi.org/10. 1371/journal.pone.0063536.

61. Lai MC, Lin Rl, Huang SY, Tsai CW, Tarn WY. A human importin-beta family protein, transportin-SR2, interacts with the phosphorylated RS domain of SR proteins. J Biol Chem. 2000;275:7950-7. https://doi.org/10.1074/jbc.275.11. 7950.

62. Lai MC, Lin RI, Tarn WY. Transportin-SR2 mediates nuclear import of phosphorylated SR proteins. Proc Natl Acad Sci U S A. 2001;98:10154-9. https://doi.org/10.1073/pnas.181354098.

63. Vieira NM, et al. A defect in the RNA-processing protein HNRPDL causes limb-girdle muscular dystrophy 1G (LGMD1G). Hum Mol Genet. 2014;23: 4103-10. https://doi.org/10.1093/hmg/ddu127.

64. Magri F, et al. The Italian limb girdle muscular dystrophy registry: relative frequency, clinical features, and differential diagnosis. Muscle Nerve. 2017;55: 55-68. https://doi.org/10.1002/mus.25192.

65. Guglieri M, et al. Clinical, molecular, and protein correlations in a large sample of genetically diagnosed Italian limb girdle muscular dystrophy patients. Hum Mutat. 2008;29:258-66. https://doi.org/10.1002/humu.20642.

66. Pantoja-Melendez CA, Miranda-Duarte A, Roque-Ramirez B, Zenteno JC. Epidemiological and molecular characterization of a Mexican population isolate with high prevalence of limb-girdle muscular dystrophy type 2A due to a novel calpain-3 mutation. PLoS One. 2017;12:e0170280. https://doi.org/ 10.1371/journal.pone.0170280.

67. El Kerch F, et al. Carrier frequency of the C.525delT mutation in the SGCG gene and estimated prevalence of limb girdle muscular dystrophy type 2C among the Moroccan population. Genet Test Mol Biomarkers. 2014;18:2536. https://doi.org/10.1089/gtmb.2013.0326.

68. Reddy HM, et al. Homozygous nonsense mutation in SGCA is a common cause of limb-girdle muscular dystrophy in Assiut, Egypt. Muscle Nerve. 2016;54:690-5. https://doi.org/10.1002/mus.25094.

69. Ankala A, et al. Ancestral founder mutations in calpain-3 in the Indian Agarwal community: historical, clinical, and molecular perspective. Muscle Nerve. 2013;47:931-7. https://doi.org/10.1002/mus.23763.

70. Hicks $D$, et al. A founder mutation in anoctamin 5 is a major cause of limbgirdle muscular dystrophy. Brain. 2011;134:171-82. https://doi.org/10.1093/ brain/awq294.

71. Santos R, et al. Private dysferlin exon skipping mutation (c.5492G $>$ a) with a founder effect reveals further alternative splicing involving exons 49-51. J Hum Genet. 2010;55:546-9. https://doi.org/10.1038/jhg.2010.60.

72. Leshinsky-Silver $E$, et al. Dysferlinopathy in the Jews of the Caucasus: a frequent mutation in the dysferlin gene. Neuromuscul Disord. 2007;17:9504. https://doi.org/10.1016/j.nmd.2007.07.010. 
73. Vilchez JJ, et al. Identification of a novel founder mutation in the DYSF gene causing clinical variability in the Spanish population. Arch Neurol. 2005;62: 1256-9. https://doi.org/10.1001/archneur.62.8.1256.

74. Frosk $P$, et al. The most common mutation in FKRP causing limb girdle muscular dystrophy type 2I (LGMD2I) may have occurred only once and is present in Hutterites and other populations. Hum Mutat. 2005;25:38-44. https://doi.org/10.1002/humu.20110.

75. Canki-Klain N, et al. Prevalence of the 550delA mutation in calpainopathy (LGMD 2A) in Croatia. Am J Med Genet A. 2004;125A:152-6. https://doi.org/ 10.1002/ajmg.a.20408.

76. Merlini L, et al. Homogeneous phenotype of the gypsy limb-girdle MD with the gamma-sarcoglycan C283Y mutation. Neurology. 2000;54:1075-9. https://doi.org/10.1212/wnl.54.5.1075

77. Lasa A, et al. Severe limb girdle muscular dystrophy in Spanish gypsies: further evidence for a founder mutation in the gamma-sarcoglycan gene. Eur J Hum Genet. 1998;6:396-9. https://doi.org/10.1038/sj.ejhg.5200197.

78. Urtasun M, et al. Limb-girdle muscular dystrophy in Guipuzcoa (Basque Country, Spain). Brain. 1998;121(Pt 9):1735-47. https://doi.org/10.1093/brain/ 121.9.1735.

79. Al-Zaidy SA, et al. A slowly progressive form of limb-girdle muscular dystrophy type 2 associated with founder mutation in the SGCG gene in Puerto Rican Hispanics. Mol Genet Genomic Med. 2015;3:92-8. https://doi. org/10.1002/mgg3.125

80. Ankala A, et al. A comprehensive genomic approach for neuromuscular diseases gives a high diagnostic yield. Ann Neurol. 2015;77:206-14. https:// doi.org/10.1002/ana.24303.

81. Nallamilli BRR, et al. Genetic landscape and novel disease mechanisms from a large LGMD cohort of 4656 patients. Ann Clin Transl Neurol. 2018;5:157487. https://doi.org/10.1002/acn3.649.

82. Ghaoui R, et al. Use of whole-exome sequencing for diagnosis of limbgirdle muscular dystrophy: outcomes and lessons learned. JAMA Neurol. 2015;72:1424-32. https://doi.org/10.1001/jamaneurol.2015.2274.

83. Reddy HM, et al. The sensitivity of exome sequencing in identifying pathogenic mutations for LGMD in the United States. J Hum Genet. 2017; 62:243-52. https://doi.org/10.1038/jhg.2016.116.

84. Bartoli M, et al. Safety and efficacy of AAV-mediated calpain 3 gene transfer in a mouse model of limb-girdle muscular dystrophy type 2A. Mol Ther. 2006;13:250-9. https://doi.org/10.1016/j.ymthe.2005.09.017.

85. Roudaut C, et al. Restriction of calpain3 expression to the skeletal muscle prevents cardiac toxicity and corrects pathology in a murine model of limbgirdle muscular dystrophy. Circulation. 2013;128:1094-104. https://doi.org/ 10.1161/CIRCULATIONAHA.113.001340.

86. Lostal W, et al. Efficient recovery of dysferlin deficiency by dual adenoassociated vector-mediated gene transfer. Hum Mol Genet. 2010;19:1897907. https://doi.org/10.1093/hmg/ddq065.

87. Krahn $\mathrm{M}$, et al. A naturally occurring human minidysferlin protein repairs sarcolemmal lesions in a mouse model of dysferlinopathy. Sci Transl Med. 2010;2:50ra69. https://doi.org/10.1126/scitranslmed.3000951.

88. Llanga T, et al. Structure-based designed nano-dysferlin significantly improves dysferlinopathy in BLA/J mice. Mol Ther. 2017;25:2150-62. https:// doi.org/10.1016/j.ymthe.2017.05.013

89. Potter RA, et al. Systemic delivery of dysferlin overlap vectors provides long-term gene expression and functional improvement for dysferlinopathy. Hum Gene Ther. 2018;29:749-62. https://doi.org/10. 1089/hum.2017.062

90. $\mathrm{Xu} \mathrm{L}$, et al. Adeno-associated virus 9 mediated FKRP gene therapy restores functional glycosylation of alpha-dystroglycan and improves muscle functions. Mol Ther. 2013;21:1832-40. https://doi.org/10.1038/mt.2013.156.

91. Qiao C, et al. Muscle and heart function restoration in a limb girdle muscular dystrophy 2I (LGMD2I) mouse model by systemic FKRP gene delivery. Mol Ther. 2014;22:1890-9. https://doi.org/10.1038/mt.2014.141.

92. Gicquel $E$, et al. AAV-mediated transfer of FKRP shows therapeutic efficacy in a murine model but requires control of gene expression. Hum Mol Genet. 2017;26:1952-65. https://doi.org/10.1093/hmg/ddx066.

93. Vannoy CH, Xiao W, Lu P, Xiao X, Lu QL. Efficacy of gene therapy is dependent on disease progression in dystrophic mice with mutations in the FKRP gene. Mol Ther Methods Clin Dev. 2017;5:31-42. https://doi.org/10. 1016/j.omtm.2017.02.002.

94. Pacak CA, et al. Long-term skeletal muscle protection after gene transfer in a mouse model of LGMD-2D. Mol Ther. 2007;15:1775-81. https://doi.org/10. 1038/sj.mt.6300246.
95. Dressman D, et al. Delivery of alpha- and beta-sarcoglycan by recombinant adeno-associated virus: efficient rescue of muscle, but differential toxicity. Hum Gene Ther. 2002;13:1631-46. https://doi.org/10.1089/ 10430340260201725 .

96. Rodino-Klapac LR, Lee JS, Mulligan RC, Clark KR, Mendell JR. Lack of toxicity of alpha-sarcoglycan overexpression supports clinical gene transfer trial in LGMD2D. Neurology. 2008;71:240-7. https://doi.org/10.1212/01.wnl. 0000306309.85301.e2.

97. Nishiyama A, et al. Recombinant adeno-associated virus type 8-mediated extensive therapeutic gene delivery into skeletal muscle of alphasarcoglycan-deficient mice. Hum Gene Ther. 2008;19:719-30. https://doi.org/ 10.1089/hum.2007.184.

98. Mendell JR, et al. Limb-girdle muscular dystrophy type 2D gene therapy restores alpha-sarcoglycan and associated proteins. Ann Neurol. 2009;66: 290-7. https://doi.org/10.1002/ana.21732.

99. Mendell JR, et al. Sustained alpha-sarcoglycan gene expression after gene transfer in limb-girdle muscular dystrophy, type 2D. Ann Neurol. 2010;68: 629-38. https://doi.org/10.1002/ana.22251.

100. Mendell JR, et al. Gene delivery for limb-girdle muscular dystrophy type 2D by isolated limb infusion. Hum Gene Ther. 2019;30:794-801. https://doi.org/ 10.1089/hum.2019.006

101. Pozsgai ER, Griffin DA, Heller KN, Mendell JR, Rodino-Klapac LR. Systemic AAV-mediated beta-sarcoglycan delivery targeting cardiac and skeletal muscle ameliorates histological and functional deficits in LGMD2E mice. Mol Ther. 2017;25:855-69. https://doi.org/10.1016/j.ymthe. 2017.02.013.

102. Pozsgai ER, Griffin DA, Heller KN, Mendell JR, Rodino-Klapac LR. Betasarcoglycan gene transfer decreases fibrosis and restores force in LGMD2E mice. Gene Ther. 2016;23:57-66. https://doi.org/10.1038/gt.2015.80.

103. Greelish JP, et al. Stable restoration of the sarcoglycan complex in dystrophic muscle perfused with histamine and a recombinant adeno-associated viral vector. Nat Med. 1999:5:439-43. https://doi.org/10.1038/7439.

104. Li J, et al. rAAV vector-mediated sarcogylcan gene transfer in a hamster model for limb girdle muscular dystrophy. Gene Ther. 1999;6:74-82. https:// doi.org/10.1038/sj.gt.3300830.

105. Xiao X, et al. Full functional rescue of a complete muscle (TA) in dystrophic hamsters by adeno-associated virus vector-directed gene therapy. J Virol. 2000;74:1436-42. https://doi.org/10.1128/jvi.74.3.1436-1442.2000.

106. Cordier L, et al. Rescue of skeletal muscles of gamma-sarcoglycan-deficient mice with adeno-associated virus-mediated gene transfer. Mol Ther. 2000;1: 119-29. https://doi.org/10.1006/mthe.1999.0019.

107. Israeli $D$, et al. An AAV-SGCG dose-response study in a gammasarcoglycanopathy mouse model in the context of mechanical stress. Mol Ther Methods Clin Dev. 2019;13:494-502. https://doi.org/10.1016/j.omtm. 2019.04.007.

108. Herson S, et al. A phase I trial of adeno-associated virus serotype 1-gammasarcoglycan gene therapy for limb girdle muscular dystrophy type 2C. Brain. 2012;135:483-92. https://doi.org/10.1093/brain/awr342.

109. Mendell JR, et al. Single-dose gene-replacement therapy for spinal muscular atrophy. N Engl J Med. 2017;377:1713-22. https://doi.org/10.1056/ NEJMoa1706198.

110. Asher DR, et al. Clinical development on the frontier: gene therapy for duchenne muscular dystrophy. Expert Opin Biol Ther. 2020;20:263-74. https://doi.org/10.1080/14712598.2020.1725469.

111. Mingozzi F, High KA. Overcoming the host immune response to adenoassociated virus gene delivery vectors: the race between clearance, tolerance, neutralization, and escape. Annu Rev Virol. 2017;4:511-34. https:// doi.org/10.1146/annurev-virology-101416-041936.

112. Colella $P$, Ronzitti G, Mingozzi F. Emerging issues in AAV-mediated in vivo gene therapy. Mol Ther Methods Clin Dev. 2018;8:87-104. https://doi.org/10. 1016/j.omtm.2017.11.007

113. Lee JJA, Maruyama R, Duddy W, Sakurai H, Yokota T. Identification of novel antisense-mediated exon skipping targets in DYSF for therapeutic treatment of dysferlinopathy. Mol Ther Nucleic Acids. 2018;13:596-604. https://doi.org/ 10.1016/j.omtn.2018.10.004

114. Demonbreun AR, et al. A gene-edited mouse model of limb-girdle muscular dystrophy 2C for testing exon skipping. Dis Model Mech. 2019;13. https:// doi.org/10.1242/dmm.040832.

115. Wyatt EJ, et al. Efficient exon skipping of SGCG mutations mediated by phosphorodiamidate morpholino oligomers. JCI Insight. 2018;3. https://doi. org/10.1172/jci.insight.99357. 
116. Selvaraj S, et al. Gene correction of LGMD2A patient-specific iPSCs for the development of targeted autologous cell therapy. Mol Ther. 2019. https:// doi.org/10.1016/j.ymthe.2019.08.011.

117. Monjaret F, et al. The phenotype of dysferlin-deficient mice is not rescued by adeno-associated virus-mediated transfer of anoctamin 5. Hum Gene Ther Clin Dev. 2013;24:65-76. https://doi.org/10.1089/humc.2012.217.

118. He B, et al. Enhancing muscle membrane repair by gene delivery of MG53 ameliorates muscular dystrophy and heart failure in delta-sarcoglycandeficient hamsters. Mol Ther. 2012;20:727-35. https://doi.org/10.1038/mt. 2012.5.

119. Gushchina LV, et al. Treatment with recombinant human MG53 protein increases membrane integrity in a mouse model of limb girdle muscular dystrophy 2B. Mol Ther. 2017;25:2360-71. https://doi.org/10.1016/j.ymthe. 2017.06.025

120. Chu ML, Moran E. The limb-girdle muscular dystrophies: is treatment on the horizon? Neurotherapeutics. 2018;15:849-62. https://doi.org/10.1007/s13311018-0648-x.

121. de Bernabe DB, et al. Mutations in the O-mannosyltransferase gene POMT1 give rise to the severe neuronal migration disorder Walker-Warburg syndrome. Am J Hum Genet. 2002;71:1033-43. https://doi.org/10.1086/ 342975.

122. Hayashi YK, et al. Selective deficiency of alpha-dystroglycan in Fukuyamatype congenital muscular dystrophy. Neurology. 2001;57:115-21. https://doi. org/10.1212/wnl.57.1.115.

123. van Reeuwijk J, et al. POMT2 mutations cause alpha-dystroglycan hypoglycosylation and Walker-Warburg syndrome. J Med Genet. 2005;42: 907-12. https://doi.org/10.1136/jmg.2005.031963.

124. Yoshida A, et al. Muscular dystrophy and neuronal migration disorder caused by mutations in a glycosyltransferase, POMGnT1. Dev Cell. 2001;1: 717-24. https://doi.org/10.1016/s1534-5807(01)00070-3.

125. Willer T, et al. ISPD loss-of-function mutations disrupt dystroglycan Omannosylation and cause Walker-Warburg syndrome. Nat Genet. 2012;44: 575-80. https://doi.org/10.1038/ng.2252

126. Roscioli T, et al. Mutations in ISPD cause Walker-Warburg syndrome and defective glycosylation of alpha-dystroglycan. Nat Genet. 2012;44:581-5. https://doi.org/10.1038/ng.2253.

127. Yoshida-Moriguchi T, et al. SGK196 is a glycosylation-specific O-mannose kinase required for dystroglycan function. Science. 2013;341:896-9. https:// doi.org/10.1126/science.1239951.

128. Kanagawa $M$, et al. Residual laminin-binding activity and enhanced dystroglycan glycosylation by LARGE in novel model mice to dystroglycanopathy. Hum Mol Genet. 2009;18:621-31. https://doi.org/10. 1093/hmg/ddn387.

129. Cataldi MP, Blaeser A, Lu P, Leroy V, Lu QL. ISPD overexpression enhances ribitol-induced glycosylation of alpha-dystroglycan in dystrophic FKRP mutant mice. Mol Ther Methods Clin Dev. 2020;17:271-80. https://doi.org/ 10.1016/j.omtm.2019.12.005.

130. Martineau LC, Gardiner PF. Insight into skeletal muscle mechanotransduction: MAPK activation is quantitatively related to tension. J Appl Physiol (1985). 2001; 91:693-702. https://doi.org/10.1152/jappl.2001.91.2.693

131. Moorwood C, et al. Absence of gamma-sarcoglycan alters the response of p7056 kinase to mechanical perturbation in murine skeletal muscle. Skelet Muscle. 2014:4:13. https://doi.org/10.1186/2044-5040-4-13.

132. Hornberger TA, Mateja RD, Chin ER, Andrews JL, Esser KA. Aging does not alter the mechanosensitivity of the p38, p70S6k, and JNK2 signaling pathways in skeletal muscle. J Appl Physiol (1985). 2005;98:1562-6. https:// doi.org/10.1152/japplphysiol.00870.2004.

133. Barton ER. Impact of sarcoglycan complex on mechanical signal transduction in murine skeletal muscle. Am J Physiol Cell Physiol. 2006;290: C411-9. https://doi.org/10.1152/ajpcell.00192.2005.

134. Barton ER. Restoration of gamma-sarcoglycan localization and mechanical signal transduction are independent in murine skeletal muscle. J Biol Chem. 2010;285:17263-70. https://doi.org/10.1074/jbc.M109.063990.

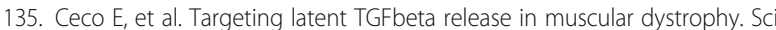
Transl Med. 2014;6:259ra144. https://doi.org/10.1126/scitranslmed.3010018.

136. Spinazzola JM, Smith TC, Liu M, Luna EJ, Barton ER. Gamma-sarcoglycan is required for the response of archvillin to mechanical stimulation in skeletal muscle. Hum Mol Genet. 2015;24:2470-81. https://doi.org/10.1093/hmg/ ddv008.

137. Muchir A et al. Inhibition of extracellular signal-regulated kinase $1 / 2$ signaling has beneficial effects on skeletal muscle in a mouse model of
Emery-Dreifuss muscular dystrophy caused by Lamin a/C gene mutation. Skelet Muscle. 2013;3:17. https://doi.org/10.1186/2044-5040-3-17.

138. Muchir A, Wu W, Sera F, Homma S, Worman HJ. Mitogen-activated protein kinase kinase 1/2 inhibition and angiotensin II converting inhibition in mice with cardiomyopathy caused by Lamin a/C gene mutation. Biochem Biophys Res Commun. 2014;452:958-61. https://doi.org/10.1016/j.bbrc.2014. 09.020 .

139. Wu W, Iwata S, Homma S, Worman HJ, Muchir A. Depletion of extracellular signal-regulated kinase 1 in mice with cardiomyopathy caused by Lamin a/ C gene mutation partially prevents pathology before isoenzyme activation. Hum Mol Genet. 2014;23:1-11. https://doi.org/10.1093/hmg/ddt387.

140. Lessard SJ, et al. JNK regulates muscle remodeling via myostatin/SMAD inhibition. Nat Commun. 2018:9:3030. https://doi.org/10.1038/s41467-01805439-3.

141. Kolodziejczyk SM, et al. Activation of JNK1 contributes to dystrophic muscle pathogenesis. Curr Biol. 2001;11:1278-82. https://doi.org/10.1016/s09609822(01)00397-9.

142. Smythe GM, Forwood JK. Altered mitogen-activated protein kinase signaling in dystrophic (mdx) muscle. Muscle Nerve. 2012;46:374-83. https://doi.org/ 10.1002/mus.23312.

143. Griffin MA, et al. Gamma-Sarcoglycan deficiency increases cell contractility, apoptosis and MAPK pathway activation but does not affect adhesion. J Cel Sci. 2005;118:1405-16. https://doi.org/10.1242/jcs.01717.

144. Oliva J, et al. Clinically advanced p38 inhibitors suppress DUX4 expression in cellular and animal models of facioscapulohumeral muscular dystrophy. J Pharmacol Exp Ther. 2019;370:219-30. https://doi.org/10.1124/jpet.119. 259663.

145. Suzuki $N$, et al. Continuous administration of poloxamer 188 reduces overload-induced muscular atrophy in dysferlin-deficient SJL mice. Neurosci Res. 2012;72:181-6. https://doi.org/10.1016/j.neures.2011.10.005.

146. Shi $\mathrm{H}$, et al. Improved regenerative myogenesis and muscular dystrophy in mice lacking Mkp5. J Clin Invest. 2013;123:2064-77. https://doi.org/10.1172/ JCl64375.

147. Wissing ER, et al. P38alpha MAPK underlies muscular dystrophy and myofiber death through a Bax-dependent mechanism. Hum Mol Genet. 2014:23:5452-63. https://doi.org/10.1093/hmg/ddu270.

148. Kramerova I, et al. Failure to up-regulate transcription of genes necessary for muscle adaptation underlies limb girdle muscular dystrophy $2 \mathrm{~A}$ (calpainopathy). Hum Mol Genet. 2016;25:2194-207. https://doi.org/10.1093/ hmg/ddw086.

149. Kumar A, Khandelwal N, Malya R, Reid MB, Boriek AM. Loss of dystrophin causes aberrant mechanotransduction in skeletal muscle fibers. FASEB J. 2004;18:102-13. https://doi.org/10.1096/fj.03-0453com.

150. Vo AH, et al. Dusp6 is a genetic modifier of growth through enhanced ERK activity. Hum Mol Genet. 2019;28:279-89. https://doi.org/10.1093/hmg/ ddy349.

151. Boyer JG, et al. ERK1/2 signaling induces skeletal muscle slow fiber-type switching and reduces muscular dystrophy disease severity. JCI Insight. 2019;5. https://doi.org/10.1172/jci.insight.127356.

152. Yoshida T, Pan Y, Hanada H, Iwata Y, Shigekawa M. Bidirectional signaling between sarcoglycans and the integrin adhesion system in cultured L6 myocytes. J Biol Chem. 1998;273:1583-90.

153. Thompson TG, et al. Filamin 2 (FLN2): a muscle-specific sarcoglycan interacting protein. J Cell Biol. 2000;148:115-26.

154. Hack AA, et al. Muscle degeneration without mechanical injury in sarcoglycan deficiency. Proc Natl Acad Sci U S A. 1999;96:10723-8.

155. Hack AA, et al. Gamma-sarcoglycan deficiency leads to muscle membrane defects and apoptosis independent of dystrophin. J Cell Biol. 1998;142: 1279-87.

156. Cuenda A, Cohen P. Stress-activated protein kinase-2/p38 and a rapamycinsensitive pathway are required for C2C12 myogenesis. J Biol Chem. 1999; 274:4341-6. https://doi.org/10.1074/jbc.274.7.4341.

157. Wu Z, et al. p38 and extracellular signal-regulated kinases regulate the myogenic program at multiple steps. Mol Cell Biol. 2000;20:3951-64. https:// doi.org/10.1128/mcb.20.11.3951-3964.2000.

158. Puigserver $P$, et al. Cytokine stimulation of energy expenditure through $p 38$ MAP kinase activation of PPARgamma coactivator-1. Mol Cell. 2001;8:97182. https://doi.org/10.1016/s1097-2765(01)00390-2.

159. Kramerova I, et al. Impaired calcium calmodulin kinase signaling and muscle adaptation response in the absence of calpain 3. Hum Mol Genet. 2012;21: 3193-204. https://doi.org/10.1093/hmg/dds144. 
160. Kramerova I, Torres JA, Eskin A, Nelson SF, Spencer MJ. Calpain 3 and CaMKIllbeta signaling are required to induce HSP70 necessary for adaptive muscle growth after atrophy. Hum Mol Genet. 2018;27:1642-53. https://doi. org/10.1093/hmg/ddy071.

161. Yalvac ME, et al. Impaired regeneration in calpain-3 null muscle is associated with perturbations in MTORC1 signaling and defective mitochondrial biogenesis. Skelet Muscle. 2017;7:27. https://doi.org/10.1186/ s13395-017-0146-6.

162. Angelini C, et al. The clinical spectrum of sarcoglycanopathies. Neurology. 1999;52:176-9.

163. Salem IH, et al. Impact of single-nucleotide polymorphisms at the TP53binding and responsive promoter region of $B C L 2$ gene in modulating the phenotypic variability of LGMD2C patients. Mol Biol Rep. 2012;39:7479-86.

164. Sandona, D. \& Betto, R. Sarcoglycanopathies: molecular pathogenesis and therapeutic prospects. Expert Rev Mol Med 11 (2009)

165. Fraysse $B$, et al. Ca2+ overload and mitochondrial permeability transition pore activation in living delta-sarcoglycan-deficient cardiomyocytes. Am J Physiol-Cell Ph. 2010;299:C706-13.

166. Kramerova I, et al. Mitochondrial abnormalities, energy deficit and oxidative stress are features of calpain 3 deficiency in skeletal muscle. Hum Mol Genet. 2009;18:3194-205. https://doi.org/10.1093/hmg/ddp257.

167. Millay DP, et al. Genetic and pharmacologic inhibition of mitochondrialdependent necrosis attenuates muscular dystrophy. Nat Med. 2008;14:4427. https://doi.org/10.1038/nm1736.

168. Pambianco $S$, et al. Reversal of defective mitochondrial biogenesis in limbgirdle muscular dystrophy 2D by independent modulation of histone and PGC-1 alpha acetylation. Cell Rep. 2016;17:3010-23.

169. Vincent $A E$, et al. Dysferlin mutations and mitochondrial dysfunction. Neuromuscul Disord. 2016;26:782-8. https://doi.org/10.1016/j.nmd.2016. 08.008 .

170. Ramirez-Sanchez I, et al. (-)-Epicatechin improves mitochondrial-related protein levels and ameliorates oxidative stress in dystrophic deltasarcoglycan null mouse striated muscle. FEBS J. 2014;281:5567-80. https:// doi.org/10.1111/febs.13098.

171. Muchir A, Shan J, Bonne G, Lehnart SE, Worman HJ. Inhibition of extracellular signal-regulated kinase signaling to prevent cardiomyopathy caused by mutation in the gene encoding A-type lamins. Hum Mol Genet. 2009;18:241-7. https://doi.org/10.1093/hmg/ddn343.

172. Kanamori $\mathrm{H}$, et al. Metformin enhances autophagy and provides cardioprotection in delta-sarcoglycan deficiency-induced dilated cardiomyopathy. Circ Heart Fail. 2019;12:e005418. https://doi.org/10.1161/ CIRCHEARTFAILURE. 118.005418

173. Hammers DW. RevAMP(K)ing mitochondria for sarcoglycanopathy therapeutics. Circ Heart Fail. 2019;12:e005873. https://doi.org/10.1161/ CIRCHEARTFAILURE.119.005873.

174. Reutenauer J, Dorchies OM, Patthey-Vuadens O, Vuagniaux G, Ruegg UT. Investigation of Debio 025, a cyclophilin inhibitor, in the dystrophic $\mathrm{mdx}$ mouse, a model for Duchenne muscular dystrophy. Br J Pharmacol. 2008; 155:574-84. https://doi.org/10.1038/bjp.2008.285.

\section{Publisher's Note}

Springer Nature remains neutral with regard to jurisdictional claims in published maps and institutional affiliations.

Ready to submit your research? Choose BMC and benefit from:

- fast, convenient online submission

- thorough peer review by experienced researchers in your field

- rapid publication on acceptance

- support for research data, including large and complex data types

- gold Open Access which fosters wider collaboration and increased citations

- maximum visibility for your research: over $100 \mathrm{M}$ website views per year

At $\mathrm{BMC}$, research is always in progress.

Learn more biomedcentral.com/submissions 